\title{
Effect of tissue composition on dose distribution in brachytherapy with various photon emitting sources
}

\author{
Mahdi Ghorbani, PhD!, Fateme Salahshour, MSc², Abbas Haghparast, PhD², Toktam Ahmadi Moghaddas, MSc², \\ Courtney Knaup, PhD ${ }^{3}$ \\ Medical Physics Research Center, Faculty of Medicine, Mashhad University of Medical Sciences, Mashhad, Iran, ${ }^{2}$ Medical Physics and Medical \\ Engineering Department, Faculty of Medicine, Kermanshah University of Medical Sciences, Kermanshah, Iran, ${ }^{3}$ Comprehensive Cancer Centers \\ of Nevada, Las Vegas, Nevada, USA
}

\begin{abstract}
Purpose: The aim of this study is to compare the dose in various soft tissues in brachytherapy with photon emitting sources.

Material and methods: ${ }^{103} \mathrm{Pd},{ }^{125} \mathrm{I},{ }^{169} \mathrm{Yb},{ }^{192} \mathrm{Ir}$ brachytherapy sources were simulated with MCNPX Monte Carlo code, and their dose rate constant and radial dose function were compared with the published data. A spherical phantom with $50 \mathrm{~cm}$ radius was simulated and the dose at various radial distances in adipose tissue, breast tissue, 4-component soft tissue, brain (grey/white matter), muscle (skeletal), lung tissue, blood (whole), 9-component soft tissue, and water were calculated. The absolute dose and relative dose difference with respect to 9-component soft tissue was obtained for various materials, sources, and distances.

Results: There was good agreement between the dosimetric parameters of the sources and the published data. Adipose tissue, breast tissue, 4-component soft tissue, and water showed the greatest difference in dose relative to the dose to the 9-component soft tissue. The other soft tissues showed lower dose differences. The dose difference was also higher for ${ }^{103} \mathrm{Pd}$ source than for ${ }^{125} \mathrm{I},{ }^{169} \mathrm{Yb}$, and ${ }^{192} \mathrm{Ir}$ sources. Furthermore, greater distances from the source had higher relative dose differences and the effect can be justified due to the change in photon spectrum (softening or hardening) as photons traverse the phantom material.

Conclusions: The ignorance of soft tissue characteristics (density, composition, etc.) by treatment planning systems incorporates a significant error in dose delivery to the patient in brachytherapy with photon sources. The error depends on the type of soft tissue, brachytherapy source, as well as the distance from the source.
\end{abstract}

Key words: brachytherapy, ICRU, photon emitting sources, relative dose, soft tissue.

\section{Purpose}

Cancer is a main cause of mortality, and the number of cancer diagnoses annually is more than ten million worldwide [1]. Among the currents cancer treatment modalities, the most common are chemotherapy, radiotherapy, and surgery [2]. As a requirement for a successful radiotherapy, it is essential to minimize the discrepancies between calculated dose distributions and delivered doses. To this end, the accurate calculation of dose distributions in the treatment planning process is paramount $[3,4]$. Tissue and water equivalent materials are routinely used in quality assurance and calibration processes involved in diagnostic radiology and radiotherapy. However, from a radiation physics point of view, currently available tissue equivalent materials show limitations in mimicking characteristics of the real tissues in low and high energy ranges [5].
Treatment planning systems (TPSs), which are used in radiotherapy, utilize correlations based on in-water measurements for evaluation of doses in the volume of interest and in other organs. TPSs exhibit errors in estimation of organ doses in some cases. For example, TPSs overestimate the dose inside heterogeneity and at points beyond it. It has been shown that the algorithms, which are employed for computations in the TPSs are not able to calculate the dose variation in heterogeneous regions as accurately as Monte Carlo methods [6-9]. In a number of previous studies, the dose distribution in various tissue-equivalent materials was calculated. Yazdani and Mowlavi have determined dosimetric parameters of a ${ }^{131} \mathrm{Cs}$ brachytherapy source (model CS-1 Rev.2), based on a Monte Carlo study. They have also calculated relative dose distributions in water and soft tissue phantoms. It was concluded that the dose deposition from photons in high gradient regions

\footnotetext{
Address for correspondence: Toktam Ahmadi Moghaddas, MSc, Medical Physics and Medical Engineering Received: 04.11.2013 Department, Faculty of Medicine, Kermanshah University of Medical Sciences, Kermanshah, Iran, Accepted: 01.03.2014 phone: +98 8314274627, fax: +98 8314274623, $₫$ e-mail: toktamt.moghadas@gmail.com

Published: 28.03.2014
} 
can be calculated accurately by Monte Carlo techniques. The results of the study can be used as input for TPSs using this source [10]. Mowlavi and Yazdani performed a similar study on a high dose rate ${ }^{169} \mathrm{Yb}$ source (model X1267), yielding similar conclusions [11]. Luxton, based on the EGS4 Monte Carlo code, has developed a model for calculation of dose rate in water for a low-energy brachytherapy source from the measurement data of dose rate to water within a solid water phantom. The model was used for calculation of the dose rate at various distances from a source in a thin shell of water within the solid phantom. It was concluded that by comparing the dose distribution with that calculated for a homogeneous water phantom, correction factors for determination of dose rate in homogeneous water medium from the measurements within the solid phantom can be derived. The correction factors were calculated for acrylic, solid water (WT1), and RW-1 phantoms with photon spectra of a ${ }^{103} \mathrm{Pd}$ and two ${ }^{125}$ I sources used as input. Among the three phantom materials evaluated for these three sources, measurements in RW-1 phantom were most similar to the corresponding values in a water phantom [12]. Furthermore, there are also other studies on various tissue-equivalent materials when phantoms irradiated by brachytherapy sources to evaluate their water equivalence and their dose distribution differences $[13,14]$.

Since the presence of inhomogeneities in a phantom affect the dose distribution, some previous studies have been focused on dose determination in the presence of inhomogeneity. Chandola et al. performed a study to find out the dose differences in the presence of inhomogeneities, in a water phantom, using a high dose rate ${ }^{192} \mathrm{Ir}$ brachytherapy source. The source, a water phantom, and inhomogeneities were simulated using Monte Carlo simulation EGSnrc code. The relative dose difference along the transverse axis of the source was 5.5-6.5\% higher and $4.5-5 \%$ lower in the presence of air and cortical bone, respectively. The results were in good agreement with other data in the literature [15]. Cazeca et al. used MCNP5 code to calculate the dose rate within planning target volume of a MammoSite balloon ${ }^{\circledR}$ (RTS Cytyc Corp, Marlborough, MA, USA) dose delivery system for evaluation of the effects of breast-air and breast-lung interfaces on the dose within this volume. An average female chest phantom and a semi-infinite water phantom, and ${ }^{169} \mathrm{Yb}$ and ${ }^{192} \mathrm{Ir}$ high dose rate brachytherapy sources were simulated. The ratio of the calculated dose rate in the planning target volume for the chest and the water phantom in the point closest to the breast-air interface was less than that in the point closest to the breast-lung interface by $11.4 \%$ and $4 \%$ for the ${ }^{169} \mathrm{Yb}$, and ${ }^{192} \mathrm{Ir}$ sources, respectively. The results imply that to avoid error in dose delivery into the patient, the software which is used for dose rate calculation in MammoSite balloon ${ }^{\circledR}$ treatments should account for patient anatomy and the density of the surrounding materials in its dosimetric analysis [16]. In a Monte Carlo study by Gialousis et al., the dose difference originating from tissue inhomogeneity was calculated. The results showed that a relative underestimation in dose by TPS calculations existed in tissues close to the radioactive source. The existence of lung tissue instead of normal tissue resulted in relative dose increase of $8 \%$ at $4-\mathrm{cm}$ from the source. Furthermore, the relative increase was $2.1 \%$ for the lung and amounted to $6.8 \%$ and $7.6 \%$ for the organs at risk such as heart and bone marrow, respectively [17]. Hsu et al. has reported dose distributions around a ${ }^{192}$ Ir brachytherapy source in various phantoms using three Monte Carlo codes. Furthermore, measurements were performed for verification of the Monte Carlo results. The results have shown that radial dose functions were influenced in bone tissue. Dose differences ranging from $0.6 \%$ to $14.4 \%$ were observed between the values in the homogeneous solid water phantoms and the solid water, which included lung interfaces. The dose difference between the bone phantoms and bone-lung interfaces ranged from $4.1 \%$ to $15.7 \%$. These results imply that there are dose distribution differences in water, bone, lung, and inhomogeneous phantoms. It was concluded that clinical parameters do not provide sufficient dose calculation accuracy for different materials, and to improve the brachytherapy treatment quality calculations, TPSs should incorporate material density [18].

In a study by White et al., the dosimetric impact of trace elements in human tissues was determined for low energy photon brachytherapy sources. White et al. have used Monte Carlo calculations to investigate the effect of trace elements in normal and cancerous tissues on the dose in brachytherapy with low-energy photon sources. Their results indicate that the presence of trace elements in tissue result in dose differences, which depend on the atomic number and concentration of the trace elements. While trace elements of low atomic number have a negligible effect in all tissues, higher atomic number elements had larger effects, which are higher than 3\%. Furthermore, the dose distributions in cancerous and healthy prostate tissues and trace element-free composition were significantly different. It was mentioned that with low-energy sources, due to the non-negligible effect on the dose in tissues, the trace elements are taken into account as a source of uncertainty in dose calculations and further investigations are needed for accurate determination of the trace composition effect in various soft tissues [19]. While various studies have evaluated the dose in various tissue-equivalent material phantoms and in one case the effect of in-tissue trace elements was evaluated, to the best of our knowledge the difference between the relative and absolute dose in various soft tissues has not been evaluated, from a comparison point of view.

The aim of this study is to compare the dose in water (as a dosimetric material reference) and various soft tissues with ICRU 9-component soft tissue [20] in brachytherapy with photon emitting sources.

\section{Material and methods \\ Brachytherapy sources}

Four brachytherapy sources were simulated in this study: ${ }^{103} \mathrm{Pd}$ (Prospera Med3633 ideal, Brachytherapy Services, Inc. CA, USA), ${ }^{125}$ I (Amersham OncoSeed 6702, Little Chalfont, United Kingdom), ${ }^{169} \mathrm{Yb}$ (4140, Implant 
Sciences Corporation, Wakefield, MA, USA), ${ }^{192}$ Ir (GammaMed 12i, Varian Medical Systems, Inc. Palo Alto, CA, USA) brachytherapy sources were simulated with MCNPX Monte Carlo code (version 2.4.0) [21]. The Med3633 ${ }^{103} \mathrm{Pd}$ source is composed of two polystyrene spheres, each having $0.560 \mathrm{~mm}$ diameter coated with a negligible thickness of radioactive ${ }^{103} \mathrm{Pd}$. The polystyrene spheres are positioned on either side of two gold/copper alloy spheres (markers) with $0.560 \mathrm{~mm}$ diameter. The seed has a titanium encapsulation, which is in the form of a cylinder with outer and inner diameter of $0.810 \mathrm{~mm}$ and $0.710 \mathrm{~mm}$, respectively. The average thickness of the weld is $0.100 \mathrm{~mm}$. The centers of the source spheres are located at $\pm 1.807 \mathrm{~mm}$ and $\pm 1.084 \mathrm{~mm}$. The centers of the markers are located at $\pm 0.361 \mathrm{~mm}$ distances from the center of the seed. The source has overall length of $4.70 \mathrm{~mm}$, while its active length is $4.20 \mathrm{~mm}$ [22].

The Amersham OncoSeed $6702{ }^{125} \mathrm{I}$ source includes three resin spheres with $1.2 \mathrm{~g} / \mathrm{cm}^{3}$ density and molecular formula of $\mathrm{C}_{12} \mathrm{H}_{18} \mathrm{NCl}$. The diameter of the resin spheres is $0.600 \mathrm{~mm}$. A negligible thickness of radioactive ${ }^{125} \mathrm{I}$ is coated on the spheres. The encapsulation of the source is composed of a titanium tube with $0.050 \mathrm{~mm}$ thickness on its walls having an outer diameter of $0.800 \mathrm{~mm}$. There are two end welds with $0.500 \mathrm{~mm}$ thickness, which are in the form of $0.400 \mathrm{~mm}$ hemispheres located on top of solid cylinders with $0.400 \mathrm{~mm}$ radius and $0.100 \mathrm{~mm}$ thickness. The active length of the source is $3.30 \mathrm{~mm}$ and its overall length is $4.50 \mathrm{~mm}$ [23].

The HDR $4140{ }^{169} \mathrm{Yb}$ source consists of a ytterbium oxide core $\left(6.9 \mathrm{~g} / \mathrm{cm}^{3}\right)$ with length of $3.60 \mathrm{~mm}$ and diameter of $0.73 \mathrm{~mm}$. The active core has a stainless steel capsule (AISI 306 with $7.80 \mathrm{~g} / \mathrm{cm}^{3}$ density). The end weld consists of a hemispherical part with $0.45 \mathrm{~mm}$ radius and a solid cylindrical part with $0.050 \mathrm{~mm}$ thickness. A hollow cylindrical section with $4.30 \mathrm{~mm}$ length is attached to the end weld. The inner and outer diameters of the hollow cylindrical section are $0.73 \mathrm{~mm}$ and $0.90 \mathrm{~mm}$, respec- tively. This hollow portion is connected to a cylindrical section with $0.60 \mathrm{~mm}$ thickness and $0.90 \mathrm{~mm}$ diameter. The source's cable is in the form of a solid cylinder made of stainless steel (AISI 306 with density of $6.90 \mathrm{~g} / \mathrm{cm}^{3}$ ) with diameter of $0.90 \mathrm{~mm}$ and length of $1.95 \mathrm{~mm}$ [24].

The GammaMed $12 \mathrm{i}{ }^{192} \mathrm{Ir}$ source consists of an active ${ }^{192} \mathrm{Ir}$ core and a stainless steel capsule. The length of the active core is $3.50 \mathrm{~mm}$ and its diameter is $0.70 \mathrm{~mm}$. The capsule has $1.10 \mathrm{~mm}$ diameter and is made of AISI 316L stainless steel with a density of $7.8 \mathrm{~g} / \mathrm{cm}^{3}$. The tip of the source, which is part of its encapsulation, has the form of a cone with $0.143 \mathrm{~mm}$ height and opening angle of $75^{\circ}$. This section is attached to solid cylindrical section with a length of $0.717 \mathrm{~mm}$ followed by a hollow section with length and inner diameter of $3.60 \mathrm{~mm}$ and $0.70 \mathrm{~mm}$, respectively. Attached to the hollow section is a $0.5 \mathrm{~mm}$ long solid cylinder. A $6 \mathrm{~cm}$ stainless steel cable (AISI 304 with density of $5.6 \mathrm{~g} / \mathrm{cm}^{3}$ ) is connected to the source [25].

A schematic diagram of the geometry of the Prospera Med3633 ${ }^{103} \mathrm{Pd}$, Amersham OncoSeed $6702{ }^{125} \mathrm{I}, 4140$ ${ }^{169} \mathrm{Yb}$ and GammaMed 12i ${ }^{192} \mathrm{Ir}$ brachytherapy sources is illustrated in Figure 1. Photon energy spectrum of ${ }^{103} \mathrm{Pd},{ }^{125} \mathrm{I},{ }^{169} \mathrm{Yb}$ and ${ }^{192} \mathrm{Ir}$ is illustrated in Table 1 [26-28]. Some of these radionuclides, such as ${ }^{169} \mathrm{Yb}$, are not as widely used as the ${ }^{192}$ Ir source. However, the four brachytherapy sources evaluated in this study, spanning a relatively wide energy range, were selected to study the energy dependency of the results.

\section{Dosimetric parameters of sources}

Dose rate constant and radial dose function of the ${ }^{103} \mathrm{Pd},{ }^{125} \mathrm{I},{ }^{169} \mathrm{Yb}$, and ${ }^{192} \mathrm{Ir}$ brachytherapy sources were calculated based on updated AAPM task group No. 43 (TG-43U1) formalism [26]. For calculation of air kerma strength, a number of torus cells containing dry air were defined at distances ranging from $1-50 \mathrm{~cm}$ from each source and air kerma rate in the cells was calculated using
A

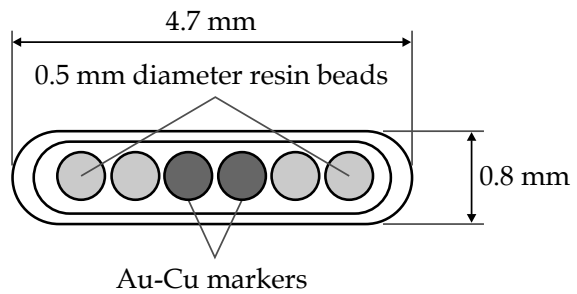

C

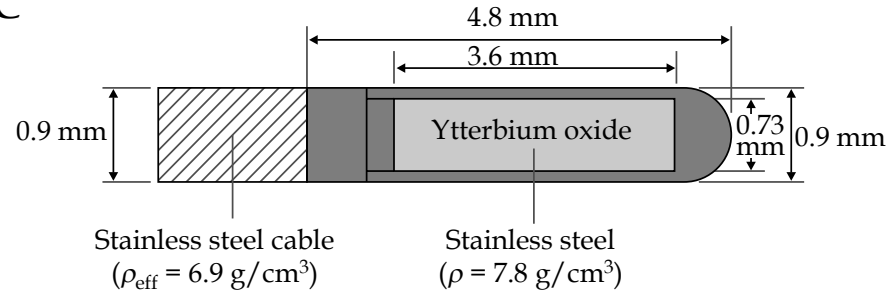

B

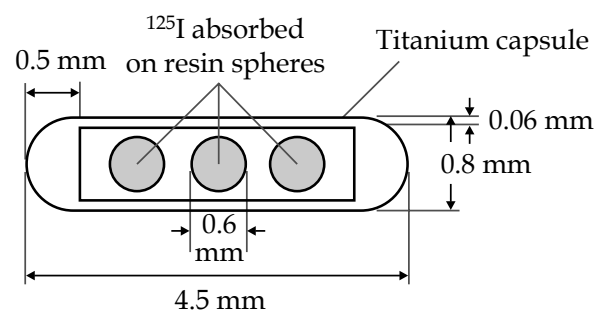

D

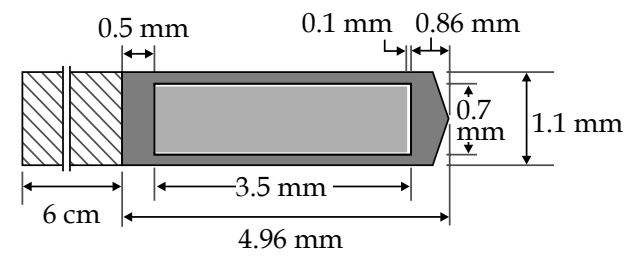

Fig. 1. A schematic diagram illustrating the geometry of (A) Prospera Med3633 ${ }^{103} \mathrm{Pd}$, (B) Amersham OncoSeed $6702{ }^{125} \mathrm{I}$, (C) $4140{ }^{169} \mathrm{Yb}$, and (D) GammaMed $12 \mathrm{i}^{192} \mathrm{Ir}$ brachytherapy sources used in this study. The dimensions are not to a real scale 
Table 1. Photon energy spectrum for ${ }^{125}$ [ [26], ${ }^{103} \mathrm{Pd}$ [26], ${ }^{169} \mathrm{Yb}$ [27], and ${ }^{192} \mathrm{Ir}$ [28] radionuclides 125 ${ }^{103} \mathrm{Pd}$ ${ }^{169} \mathrm{Yb}$

${ }^{192} \mathrm{Ir}$

\begin{tabular}{|c|c|c|c|c|c|c|c|}
\hline Energy (keV) & Intensity (\%) & Energy (keV) & Intensity (\%) & Energy (keV) & Intensity (\%) & Energy (keV) & Intensity (\%) \\
\hline 27.202 & 0.405 & 22.074 & 0.224 & 49.77 & 53.2 & 61.49 & 1.20 \\
\hline 27.472 & 0.756 & 20.216 & 0.423 & 50.74 & 94.0 & 63.00 & 2.07 \\
\hline 30.980 & 0.201 & 22.717 & 0.104 & 57.60 & 29.5 & 65.12 & 2.65 \\
\hline 31.877 & 0.0438 & 23.312 & 0.0194 & 59.10 & 8.2 & 66.83 & 4.53 \\
\hline \multirow[t]{22}{*}{35.4919} & 0.0466 & 39.755 & 0.000683 & 63.10 & 44.2 & 71.08 & 0.24 \\
\hline & & 62.51 & 0.0000104 & 93.62 & 2.6 & 71.41 & 0.46 \\
\hline & & 294.52 & 0.000028 & 109.78 & 17.5 & 73.36 & 0.16 \\
\hline & & 357.46 & 0.000221 & 118.19 & 1.9 & 75.37 & 0.53 \\
\hline & & 497.054 & 0.0000401 & 130.52 & 11.3 & 75.75 & 1.03 \\
\hline & & & & 177.21 & 22.2 & 77.83 & 0.37 \\
\hline & & & & 197.96 & 35.8 & 136.34 & 0.18 \\
\hline & & & & 261.08 & 1.7 & 201.31 & 0.47 \\
\hline & & & & 307.74 & 10.1 & 205.80 & 3.30 \\
\hline & & & & & & 283.27 & 0.26 \\
\hline & & & & & & 295.96 & 28.67 \\
\hline & & & & & & 308.46 & 30.00 \\
\hline & & & & & & 316.51 & 82.81 \\
\hline & & & & & & 374.49 & 0.72 \\
\hline & & & & & & 416.47 & 0.66 \\
\hline & & & & & & 468.07 & 47.83 \\
\hline & & & & & & 484.58 & 3.18 \\
\hline & & & & & & 489.04 & 0.44 \\
\hline & & & & & & 588.58 & 4.52 \\
\hline & & & & & & 604.41 & 8.23 \\
\hline & & & & & & 612.47 & 5.31 \\
\hline & & & & & & 884.54 & 0.29 \\
\hline \multicolumn{2}{|c|}{ Mean energy $=28.37 \mathrm{keV}$} & Mean energ & $=20.74 \mathrm{keV}$ & Mean energ & $y=92.7 \mathrm{keV}$ & Mean ener & $y=350 \mathrm{keV}$ \\
\hline
\end{tabular}

F6 tally. Air kerma rate $\times r^{2}$ was plotted versus $r(\mathrm{~cm})$ and its average in the relatively flat region of the plot (2$30 \mathrm{~cm}$ ) was used toward calculation of air kerma strength. Air torus cells were located in a vacuum medium. The Monte Carlo calculation type A statistical uncertainties were less than $0.45 \%$. Type A statistical uncertainty refers to random error [29]. Dose rate in water was scored using * $\mathrm{F} 8$ tally, and then dose at $1 \mathrm{~cm}$ distance from the source was divided to the value of air kerma strength and dose rate constant $\left(\mathrm{cGy} \mathrm{h}^{-1} \mathrm{U}^{-1}\right)$ was calculated. The water phantom in this calculation was a sphere with $50 \mathrm{~cm}$ radius. The Monte Carlo errors in the tally cell for calculation of the dose were maximally $0.32 \%$.

Geometry function was calculated using the linesource approximation and then was used for calculation of radial dose function. For the calculation of radial dose function, a water phantom as a sphere with $50 \mathrm{~cm}$ radius was defined and dose values at distances ranging from 0.5-7 cm was calculated by utilizing *F8 tally. The calculation of radial dose function was based on equation No. 6 of TG-43U1 formalism [26]. In this section, for all the sources, $1.5 \times 10^{8}$ photons were scored. The maximum Monte Carlo error in the tally cells was $4.22 \%$ for the case of calculation of radial dose function.

\section{The effect of tissue composition}

Mass density and composition (fraction by weight) of adipose tissue, breast tissue, 4-component soft tissue, brain (grey/white matter), muscle (skeletal), lung tissue, blood (whole), and 9-component soft tissue were adopted from the report No. 44 of the International Commission on Radiation Units and Measurements (ICRU) [20]. Mass density and the composition of the mentioned tissues and water are listed in Table 2. Each source and phantom material was simulated using MCNPX (version 2.4.0) code [21]. To have an acceptable level of Monte Carlo type A statistical uncertainty within a reasonable computation time, the absorbed dose was determined by calculation of the photon flux and then multiplication of the flux 
Table 2. Mass density and composition (fraction by weight) of various tissues evaluated in this study. The data are extracted from ICRU-44 report

\begin{tabular}{lcccccccccc} 
& $\begin{array}{c}\text { Adipose } \\
\text { tissue }\end{array}$ & $\begin{array}{c}\text { Breast } \\
\text { tissue }\end{array}$ & $\begin{array}{c}\text { Soft tissue } \\
\text { (4-compo- } \\
\text { nent) }\end{array}$ & $\begin{array}{c}\text { Brain } \\
\text { (grey/ } \\
\text { white } \\
\text { matter) }\end{array}$ & $\begin{array}{c}\text { Muscle } \\
\text { (skeletal) }\end{array}$ & $\begin{array}{c}\text { Lung } \\
\text { tissue }\end{array}$ & $\begin{array}{c}\text { Blood } \\
\text { (whole) }\end{array}$ & $\begin{array}{c}\text { Soft tissue } \\
\text { (9-compo- } \\
\text { nent) }\end{array}$ & Water \\
\hline Density $\left(\mathrm{g} / \mathrm{cm}^{3}\right)$ & 0.95 & 1.02 & 1.00 & 1.04 & 1.05 & 1.05 & 1.06 & 1.06 & 1.00 \\
\hline $\mathrm{H}$ & 0.114000 & 0.106000 & 0.101174 & 0.107000 & 0.102000 & 0.103000 & 0.102000 & 0.102000 & 0.111111 \\
\hline $\mathrm{C}$ & 0.598000 & 0.332000 & 0.111000 & 0.145000 & 0.143000 & 0.105000 & 0.110000 & 0.143000 & - \\
\hline $\mathrm{N}$ & 0.007000 & 0.030000 & 0.026000 & 0.022000 & 0.034000 & 0.031000 & 0.033000 & 0.034000 & - \\
\hline $\mathrm{O}$ & 0.278000 & 0.527000 & 0.761826 & 0.712000 & 0.710000 & 0.749000 & 0.745000 & 0.708000 & 0.888889 \\
\hline $\mathrm{Na}$ & 0.001000 & 0.001000 & - & 0.002000 & 0.001000 & 0.002000 & 0.001000 & 0.002000 & - \\
\hline $\mathrm{P}$ & - & 0.001000 & - & 0.004000 & 0.002000 & 0.002000 & 0.001000 & 0.003000 & - \\
\hline $\mathrm{S}$ & 0.001000 & 0.002000 & - & 0.002000 & 0.003000 & 0.003000 & 0.002000 & 0.003000 & - \\
\hline $\mathrm{Cl}$ & 0.001000 & 0.001000 & - & 0.003000 & 0.001000 & 0.003000 & 0.003000 & 0.002000 & - \\
\hline $\mathrm{K}$ & - & - & - & 0.003000 & 0.004000 & 0.002000 & 0.002000 & 0.003000 & - \\
\hline $\mathrm{Fe}$ & - & - & - & - & - & - & 0.001000 & - & -
\end{tabular}

with mass energy absorption coefficient of the soft tissue. For this purpose, the energy flux $\left(\mathrm{MeV} / \mathrm{cm}^{2}\right)$ per source particle at various distances from the source in a $50 \mathrm{~cm}$ radius spherical phantom containing the soft tissue was calculated using the *F4 tally, and then was converted to the absorbed dose by multiplication with the mass energy absorption coefficients for the soft tissue extracted from the NIST database [30]. Since the mass energy absorption coefficient depends on the photon energy, the energy was divided in various bins and the flux multiplication was performed at each energy bin. This calculation was repeated for each soft tissue using mass energy absorption coefficient of that tissue. Each input file for ${ }^{103} \mathrm{Pd}$ source was run for $3 \times 10^{8}$ photon histories and the maximum Monte Carlo type A statistical uncertainty was $4.26 \%$. The input files for other sources were run for $1.5 \times 10^{8}$ photons, and the maximum Monte Carlo type A statistical uncertainty was $1.41 \%$. The number of photons scored for ${ }^{103} \mathrm{Pd}$ source was more than for other sources, because for ${ }^{103} \mathrm{Pd}$ source, the MC errors in the tally cells were being reduced with a slower speed. The relative dose in adipose tissue, breast tissue, 4-component soft tissue, brain (grey/white matter), muscle (skeletal), lung tissue, blood (whole), and water, to dose in 9-component soft tissue was calculated.

Mass energy absorption coefficient and effective atomic number $\left(Z_{\text {eff }}\right)$ for total photon-energy absorption of adipose tissue, breast tissue, 4-component soft tissue, brain (grey/white matter), muscle (skeletal), lung tissue, blood (whole), 9-component soft tissue, and water at 20, 30, 100, and $300 \mathrm{keV}$ photon energies are listed in Table 3. Among a number of values in a relatively wide range of photon

Table 3. Mass energy absorption coefficient values $\left(\mathrm{g} / \mathrm{cm}^{2}\right)$ [30] and $Z_{\text {eff }}$ values for total photon-energy absorption of various tissues and water [31] in 20, 30, 100, and $300 \mathrm{keV}$ photon energies

\begin{tabular}{lcccccccccc}
$\begin{array}{l}\text { Photon energy } \\
(\mathrm{keV})\end{array}$ & & $\begin{array}{c}\text { Adipose } \\
\text { tissue }\end{array}$ & $\begin{array}{c}\text { Breast } \\
\text { tissue }\end{array}$ & $\begin{array}{c}\text { Soft } \\
\text { tissue } \\
\text { (4-com- } \\
\text { ponent) }\end{array}$ & $\begin{array}{c}\text { Brain } \\
\text { (grey/ } \\
\text { white } \\
\text { matter) }\end{array}$ & $\begin{array}{c}\text { Muscle } \\
\text { (skele- } \\
\text { tal) }\end{array}$ & $\begin{array}{c}\text { Lung } \\
\text { tissue }\end{array}$ & $\begin{array}{c}\text { Blood } \\
\text { (whole) }\end{array}$ & $\begin{array}{c}\text { Soft } \\
\text { tissue } \\
(9-\text {-com- } \\
\text { ponent) }\end{array}$ & Water \\
\hline 20 & $\mu_{\text {en }}$ & 0.32510 & 0.43940 & 0.50700 & 0.57060 & 0.56380 & 0.57400 & 0.58310 & 0.56630 & 0.55030 \\
\cline { 2 - 11 } & $Z_{\text {eff }}$ & 4.9032 & 5.4105 & 5.7460 & 5.8629 & 5.9085 & 5.9409 & 5.9873 & 5.9169 & 5.7826 \\
\hline 30 & $\mu_{\text {en }}$ & 0.09495 & 0.12600 & 0.14380 & 0.16290 & 0.16100 & 0.16350 & 0.16690 & 0.16160 & 0.15570 \\
\hline & $Z_{\text {eff }}$ & 4.1280 & 4.6653 & 5.0403 & 5.0971 & 5.1532 & 5.1749 & 5.2157 & 5.1590 & 5.0282 \\
\hline 100 & $\mu_{\text {en }}$ & 0.02433 & 0.02478 & 0.02501 & 0.02558 & 0.02544 & 0.02550 & 0.02559 & 0.02545 & 0.02546 \\
\hline & $Z_{\text {eff }}$ & 3.1286 & 3.3623 & 3.5490 & 3.4549 & 3.5353 & 3.5379 & 3.5542 & 3.5364 & 3.4313 \\
\hline$\mu_{\text {en }}$ & 0.03194 & 0.03173 & 0.03161 & 0.03178 & 0.03164 & 0.03167 & 0.03164 & 0.03164 & 0.03192 \\
\hline & $Z_{\text {eff }}$ & 3.0779 & 3.2918 & 3.4648 & 3.3627 & 3.4422 & 3.4432 & 3.4569 & 3.4429 & 3.3432
\end{tabular}


energies, only those at 20,30, 100, and $300 \mathrm{keV}$ energies were presented in Table 3 . Selection of these energies was based on the average photon energies emitted by the ${ }^{103} \mathrm{Pd}$ (average $20.74 \mathrm{keV}$ (TG43-U1 [26]), ${ }^{125} \mathrm{I}$ (average $28.37 \mathrm{keV}$ (TG43U1 [26]), ${ }^{169} \mathrm{Yb}$ (average $92.7 \mathrm{keV}$ ), and ${ }^{192} \mathrm{Ir}$ (average $350 \mathrm{keV}$ ) radionuclides.

\section{Calculation of relative and absolute dose for the sources}

Relative dose was defined as the ratio of dose in the adipose tissue, breast tissue, 4-component soft tissue, brain (grey/white matter), muscle (skeletal), lung tissue, blood (whole), and water, to the dose of 9-component soft tissue (as a reference tissue in most studies). These values were calculated in torus cells at $0.2,0.3,0.5,1,2,3,4,5$, $7,10,12$, and $15 \mathrm{~cm}$ radial distances relative to the aforementioned sources to examine how the trend of relative dose changes with the distance.

Relative dose with respect to the dose of 9-component soft tissue alone may not have much significance, because its value changes with the energy of the source and also with radial distance from each source. Furthermore, because of a relatively high dose gradient near the source, this value alone would not be clinically meaningful. To have an interpretation of the variation of the dose rate with these parameters, the value of dose rate $\left(\mathrm{cGy} \mathrm{h}^{-1} \mathrm{U}^{-1}\right)$ in the adipose tissue, breast tissue, 4-component soft tissue, brain (grey/white matter), muscle (skeletal), lung tissue, blood (whole), 9-component soft tissue, and water was calculated at various radial distances from the sources as well. The method for calculation of dose in these tissues was the same as the aforementioned method. In other words, the flux was calculated and then converted to dose by multiplication by mass energy absorption coefficient of each soft tissue. The Monte Carlo output $(\mathrm{MeV} / \mathrm{g}$ per photon) was converted to dose rate $\left(\mathrm{cGy} \mathrm{h}^{-1} \mathrm{U}^{-1}\right)$ as described below:

Dose rate $\left(\mathrm{cGy} \mathrm{h}^{-1} \mathrm{U}^{-1}\right)=\mathrm{MC}$ output $(\mathrm{MeV} / \mathrm{g}$ per photon) $\times 10^{6}(\mathrm{eV} / \mathrm{MeV}) \times 1.602 \times 10^{-19}(\mathrm{~J} / \mathrm{eV}) \times 1000$ $(\mathrm{g} / \mathrm{kg}) \times 1($ dis $/ \mathrm{s}$ per $\mathrm{Bq}) \times$ source activity $(\mathrm{Bq} /$ per $\mathrm{U}) \times$ $\times$ photon yield of the source (photons/dis) $\times 3600(\mathrm{~s} / \mathrm{h}) \times$ $\times 100$ (cGy/Gy).

\section{Calculation of photon spectrum}

In order to interpret the results of dose differences in various soft tissues at various radial distances from the source, it is useful to know the change in photon spectrum at various distances from the sources. Therefore, the photon spectra at $0.2,1,5,10$, and $15 \mathrm{~cm}$ from the ${ }^{103} \mathrm{Pd},{ }^{125} \mathrm{I},{ }^{169} \mathrm{Yb}$, and ${ }^{192} \mathrm{Ir}$ sources were calculated. For this purpose, torus cells were defined at the stated distances from each source and the photon flux in the cells were calculated using F4 tally. The flux was calculated in various energy bins with $20 \mathrm{keV}$ energy intervals for ${ }^{103} \mathrm{Pd},{ }^{169} \mathrm{Yb}$ and ${ }^{192} \mathrm{Ir}$ sources. In the case of ${ }^{125} \mathrm{I}$, energy bins were assigned $5 \mathrm{keV}$. To have an acceptable level of Monte Carlo error in the tally cells in calculation of photon flux, the importance of photons and electrons in the tally cells was set as 50, while the importance in other cells was defined equal to 1 . The input files were run for $2 \times 10^{9}$ particles for ${ }^{103} \mathrm{Pd},{ }^{125} \mathrm{I},{ }^{169} \mathrm{Yb}$, and $5 \times 10^{8}$ for ${ }^{192} \mathrm{Ir}$ source. However, a Monte Carlo error of about $30 \%$ was observed in flux calculation for the farthest cell for ${ }^{103} \mathrm{Pd}$ source, the error of tally calculation for other cells and sources was significantly less than this level. The energy spectrum was plotted for the $0.2,1,5,10$, and $15 \mathrm{~cm}$ distances for each brachytherapy source.

\section{Results}

\section{TG-43 dosimetric parameters}

Dose rate constant and radial dose function values for the ${ }^{103} \mathrm{Pd},{ }^{125} \mathrm{I},{ }^{169} \mathrm{Yb}$, and ${ }^{192} \mathrm{Ir}$ sources obtained in this study are listed in Table 4 and Table 5. These tables also include the corresponding values from other studies for the same source models, and also the percentage differences (\%) between the data from this study and the literature.

\section{The effect of tissue composition}

The relative dose with respect to 9-component soft tissue dose for adipose tissue, breast tissue, 4-component soft tissue, brain (grey/white matter), muscle (skeletal), lung tissue, blood (whole), and water in the case of ${ }^{103} \mathrm{Pd}$, ${ }^{125} \mathrm{I},{ }^{169} \mathrm{Yb}$, and ${ }^{192} \mathrm{Ir}$ brachytherapy source models is presented in Table 6 . The relative dose here means the ratio of dose in soft tissue (for example adipose) to dose in 9-component soft tissue. The relative dose values were listed in this table for various radial distances from each source ranging from $0.2-15 \mathrm{~cm}$.

The dose rate $\left(\mathrm{cGy} \mathrm{h}^{-1} \mathrm{U}^{-1}\right)$ in various soft tissues for the four brachytherapy sources at various radial distances from each source is listed in Table 7. While the data in the $0.2-4.0 \mathrm{~cm}$ distances were rounded to two decimals in this Table, to show the differences in a number of data points with low dose values, the data in these points were

Table 4. Dose rate constant $\left(\mathrm{cGy} \mathrm{h} \mathrm{h}^{-1} \mathrm{U}^{-1}\right)$ for the ${ }^{103} \mathrm{Pd},{ }^{125} \mathrm{I},{ }^{169} \mathrm{Yb},{ }^{192} \mathrm{Ir}$ brachytherapy sources and the percentage difference (Diff. [\%]) between the values presented here with previously published data

\begin{tabular}{lccc}
\hline Source (model) & Present study & Other study (Reference) & Diff. (\%) \\
\hline${ }^{103} \mathrm{Pd}$ (Prospera Med3633 ideal) & 0.652 & 0.672 (Rivard et al. [32]) & 2.93 \\
\hline${ }^{125}$ (Amersham OncoSeed 6702) & 1.069 & 1.036 (TG-43U1 [26]) & -3.22 \\
\hline${ }^{169} \mathrm{Yb}$ (4140) & 1.191 & 1.186 (Taylor et al. [33]) & -0.43 \\
\hline${ }^{192}$ Ir (GammaMed 12i) & 1.139 & 1.122 (Pérez-Calatayud et al. [34]) & -1.48
\end{tabular}



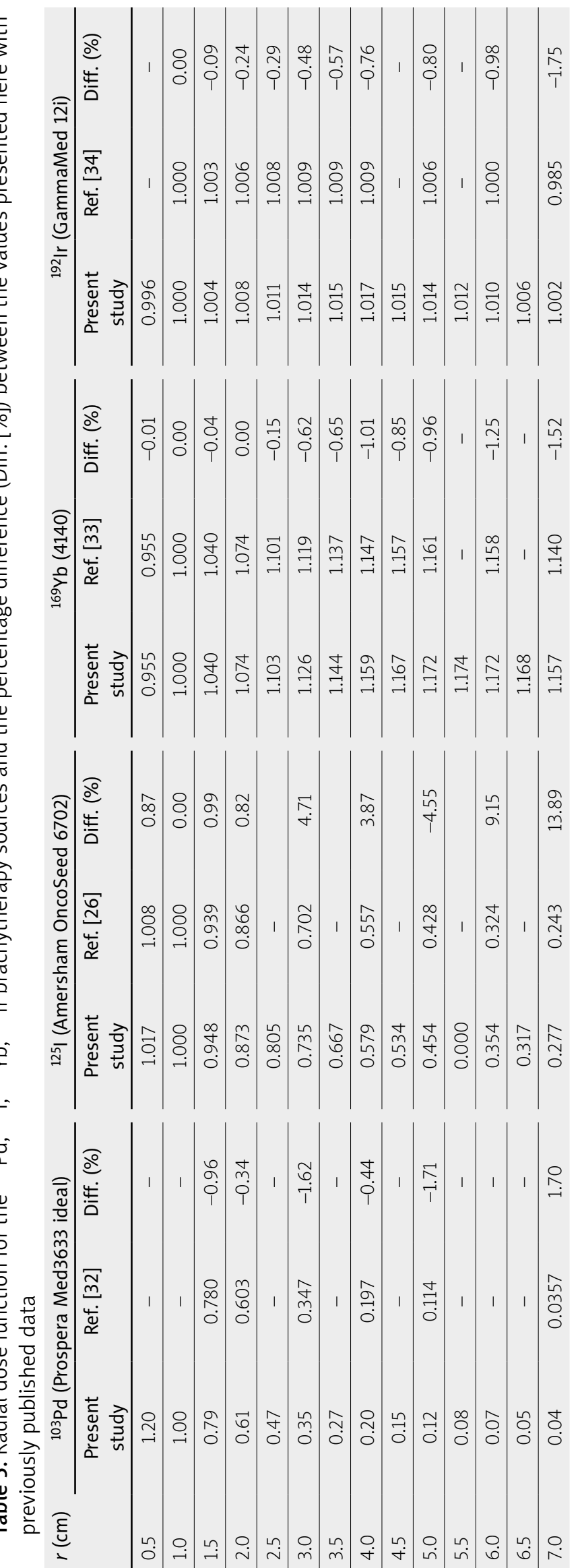

presented up to four decimals. Figure 2 demonstrates the dose rate $\left(\mathrm{cGy} \mathrm{h}^{-1} \mathrm{U}^{-1}\right)$ versus radial distance $(\mathrm{cm})$ for various soft tissues and ${ }^{103} \mathrm{Pd},{ }^{125} \mathrm{I},{ }^{169} \mathrm{Yb}$, and ${ }^{192} \mathrm{Ir}$ source models. In this figure, dose rate values were only plotted to $2 \mathrm{~cm}$ from each source, because dose rate values beyond this distance may not include any important information on the graphs.

\section{Photon spectrum at various distances from the sources}

The photon spectra at $0.2,1,5,10$, and $15 \mathrm{~cm}$ distances from the ${ }^{103} \mathrm{Pd},{ }^{125} \mathrm{I},{ }^{169} \mathrm{Yb}$, and ${ }^{192} \mathrm{Ir}$ source models are illustrated in Figure 3 . The spectra plots are the normalized number of photons per history to the total number of photons inside cells defined at mentioned distances versus photon energy (keV) in 9-component soft tissue.

The average photon energies on the spectra for ${ }^{103} \mathrm{Pd}$, ${ }^{125} \mathrm{I},{ }^{169} \mathrm{Yb}$, and ${ }^{192} \mathrm{Ir}$ sources at $0.2,1,5,10$, and $15 \mathrm{~cm}$ distances from the sources in a 9-component soft tissue phantom are presented in Table 8. The data in this table can be used toward interpretation of the variation of relative dose in various soft tissues with distance from the source.

\section{Discussion}

In the present study, four photon emitting brachytherapy sources were simulated and validation simulations were used to evaluate the effect of tissue composition on dose for a number of tissue types. Agreement within 2-5\% for anisotropy functions were obtained, compared to the supplement to the of TG-43 updated report (TG-43U1S1) [35]. Considering this criterion as excellent agreement, it can be seen in Table 4 that dose rate constant values of the present study are in excellent agreement with the previously published data. Ignoring some exceptions, the calculated radial dose functions for ${ }^{103} \mathrm{Pd},{ }^{125} \mathrm{I},{ }^{169} \mathrm{Yb}$, and ${ }^{192}$ Ir sources (Table 5) at almost all the data points show excellent agreement when compared to the radial dose functions reported in other studies. The calculated dosimetric parameters were used as the reference values for the simulated source models.

The results of the present study (Table 6 and Table 7) indicate that the differences in the composition of various soft tissues can influence the dose distribution. The effect is considerable and under similar conditions, the dose distribution in each soft tissue differs from the others. This effect implies that by equating various tissues in dose calculations with TPSs in brachytherapy by photon emitting sources, especially by lower energy sources, a significant error is introduced. A similar effect is observed for water as a tissue-equivalent material. The values of relative dose in Table 6 and the absolute dose values in Table 7 for water indicate that the dose in water significantly differs from the dose in 9-component soft tissue. This fact can be justified by comparing the mass energy absorption coefficient, and $Z_{\text {eff }}$ of water and 9-component soft tissue presented in Table 3 . This effect implies that dosimetry using water as a tissue equivalent medium, and extension of the in-water dose values for soft tissue, incorporates 


\begin{tabular}{|c|c|c|c|c|c|c|c|c|c|c|c|c|c|c|c|c|c|c|c|c|c|c|}
\hline 离 & 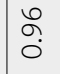 & $\begin{array}{l}\hat{a} \\
0 \\
0\end{array}$ & ô & $\left|\begin{array}{l}\infty \\
0 \\
0 \\
0\end{array}\right|$ & $\underset{\rightarrow}{\vec{T}}$ & $\stackrel{C}{-}_{-}^{+}$ & 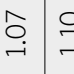 & $\stackrel{9}{\rightarrow} \underset{-7}{=}$ & 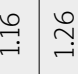 & $\underset{\sim}{\tilde{M}}$ & $\stackrel{\text { 号 }}{\rightarrow}$ & $\underset{\sim}{\vec{\sigma}}$ & $\overrightarrow{\stackrel{T}{\rightarrow}}$ & ت્ન & ه্] & $\underset{\sim}{\overrightarrow{-}}$ & & $\overrightarrow{-i}$ & $\vec{T}_{-i} \underset{-}{\overrightarrow{-}}$ & $\underset{\sim}{\stackrel{\sim}{\sim}}$ & $\underset{\sim}{\stackrel{\sim}{\sim}}$ & $\underset{\sim}{\tilde{i}}$ \\
\hline$\frac{0}{0}$ & 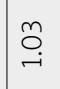 & 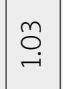 & $\stackrel{m}{\stackrel{m}{r}}$ & $\underset{\sim}{\tilde{-}}$ & 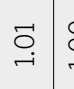 & $\underset{\rightarrow}{\stackrel{8}{-}}$ & 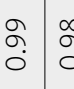 & 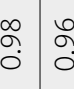 & 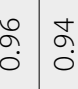 & ñ. & ने & $\underset{\rightarrow}{\stackrel{\leftrightarrow}{\rightarrow}}$ & $\underset{-}{\stackrel{\leftrightarrow}{-}}$ & $\stackrel{8}{\circ}$ & $\stackrel{8}{8}$ & $\stackrel{8}{\stackrel{8}{-}}$ & & 8 & ${ }_{i}$ & $\underset{-}{8}$ & $\stackrel{8}{\circ}$ & \& \\
\hline 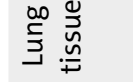 & $\underset{\sim}{\vec{\top}}$ & $\vec{\leftrightarrow}$ & $\underset{\vec{r}}{\vec{\sim}}$ & $\vec{\sim}$ & $\overrightarrow{\stackrel{\sigma}{\rightarrow}}$ & $\underset{\rightarrow}{\vec{T}}$ & $\underset{-}{\overrightarrow{-}}$ & 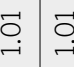 & 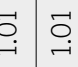 & $\underset{\rightarrow}{\vec{T}}$ & $\underset{\sim}{\tilde{\sigma}}$ & $\underset{\sim}{\stackrel{\leftrightarrow}{\rightarrow}}$ & 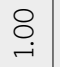 & $\underset{-}{\stackrel{-}{-}}$ & & $\underset{\sim}{\stackrel{\leftrightarrow}{\rightarrow}}$ & $\underset{-}{8}$ & $\underset{\sim}{\stackrel{\text { f }}{ }}$ & 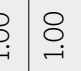 & $\underset{-}{\stackrel{-}{-}}$ & $\underset{-i}{\stackrel{一}{-}}$ & $\underset{-}{\stackrel{8}{-}}$ \\
\hline 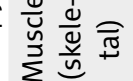 & $\begin{array}{l}\text { ôे } \\
\text { ôे }\end{array}$ & مे & 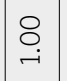 & $\underset{-i}{8}$ & 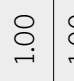 & $\underset{+}{\stackrel{8}{-}}$ & 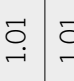 & 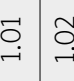 & 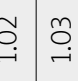 & $\underset{\sim}{\tilde{r}}$ & $\underset{\rightarrow}{\stackrel{i}{-}}$ & $\stackrel{8}{\circ}$ & $\underset{i}{8}$ & $\underset{-}{8}$ & $\stackrel{8}{8}$ & $\underset{-i}{\stackrel{8}{-}}$ & $\stackrel{8}{8}$ & 8 & 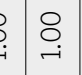 & 움 & $\underset{-}{8}$ & \\
\hline
\end{tabular}

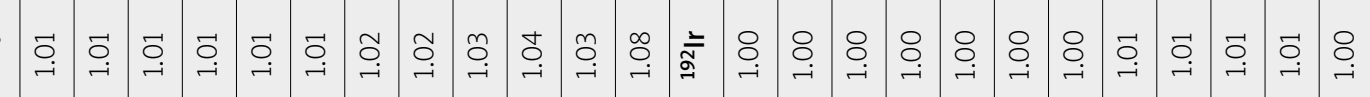

空

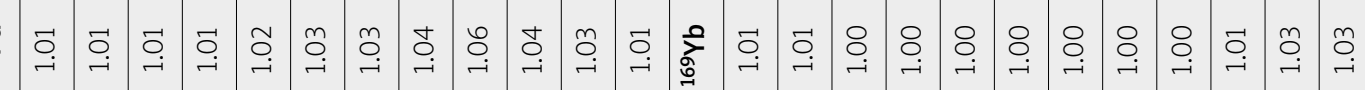
索 
Table 7. Dose rate (cGy h $\left.{ }^{-1} \mathrm{U}^{-1}\right)$ in various soft tissues for ${ }^{103} \mathrm{Pd},{ }^{125} \mathrm{I},{ }^{169} \mathrm{Yb}$, and ${ }^{192} \mathrm{Ir}$ brachytherapy sources

\begin{tabular}{|c|c|c|c|c|c|c|c|c|c|c|}
\hline \multirow[t]{2}{*}{$r(\mathrm{~cm})$} & & $\begin{array}{l}\text { Adipose } \\
\text { tissue }\end{array}$ & $\begin{array}{l}\text { Breast } \\
\text { tissue }\end{array}$ & $\begin{array}{c}\text { Soft } \\
\text { tissue } \\
\text { (4-compo- } \\
\text { nent) }\end{array}$ & $\begin{array}{c}\text { Brain } \\
\text { (grey/ } \\
\text { white } \\
\text { matter) } \\
\end{array}$ & $\begin{array}{c}\text { Muscle } \\
\text { (skeletal) }\end{array}$ & $\begin{array}{l}\text { Lung } \\
\text { tissue }\end{array}$ & $\begin{array}{c}\text { Blood } \\
\text { (whole) }\end{array}$ & $\begin{array}{c}\text { Soft } \\
\text { tissue } \\
\text { (9-compo- } \\
\text { nent) }\end{array}$ & Water \\
\hline & & \multicolumn{9}{|c|}{ Dose rate (cGy h-1 U-1) } \\
\hline \multirow[t]{12}{*}{${ }^{103} \mathrm{Pd}$} & 0.2 & 9.65 & 16.57 & 14.45 & 16.01 & 15.82 & 16.07 & 16.29 & 15.86 & 15.55 \\
\hline & 0.3 & 5.40 & 9.16 & 7.94 & 8.72 & 8.62 & 8.75 & 8.85 & 8.64 & 8.50 \\
\hline & 0.5 & 2.21 & 3.65 & 3.12 & 3.37 & 3.33 & 3.37 & 3.40 & 3.33 & 3.31 \\
\hline & 1.0 & 0.55 & 0.83 & 0.69 & 0.71 & 0.70 & 0.71 & 0.71 & 0.70 & 0.72 \\
\hline & 2.0 & 0.11 & 0.14 & 0.11 & 0.10 & 0.10 & 0.10 & 0.10 & 0.10 & 0.11 \\
\hline & 3.0 & 0.04 & 0.04 & 0.03 & 0.03 & 0.03 & 0.02 & 0.02 & 0.02 & 0.03 \\
\hline & 4.0 & 0.01 & 0.01 & 0.01 & 0.01 & 0.01 & 0.01 & 0.01 & 0.01 & 0.01 \\
\hline & 5.0 & 0.0066 & 0.0056 & 0.0037 & 0.0027 & 0.0027 & 0.0026 & 0.0024 & 0.0026 & 0.0033 \\
\hline & 7.0 & 0.0017 & 0.0011 & 0.0006 & 0.0004 & 0.0004 & 0.0004 & 0.0003 & 0.0004 & 0.0005 \\
\hline & 10.0 & 0.0003 & 0.0001 & 0.0001 & 0.0000 & 0.0000 & 0.0000 & 0.0000 & 0.0000 & 0.0001 \\
\hline & 12.0 & 0.0001 & 0.0000 & 0.0000 & 0.0000 & 0.0000 & 0.0000 & 0.0000 & 0.0000 & 0.0000 \\
\hline & 15.0 & 0.0000 & 0.0000 & 0.0000 & 0.0000 & 0.0000 & 0.0000 & 0.0000 & 0.0000 & 0.0000 \\
\hline \multirow[t]{12}{*}{125} & 0.2 & 15.52 & 20.49 & 23.29 & 26.24 & 25.93 & 26.32 & 26.85 & 26.07 & 25.15 \\
\hline & 0.3 & 7.67 & 10.08 & 11.43 & 12.83 & 12.68 & 12.87 & 13.12 & 12.75 & 12.32 \\
\hline & 0.5 & 3.00 & 3.89 & 4.38 & 4.88 & 4.83 & 4.90 & 4.98 & 4.85 & 4.71 \\
\hline & 1.0 & 0.80 & 1.00 & 1.11 & 1.21 & 1.20 & 1.21 & 1.23 & 1.20 & 1.18 \\
\hline & 2.0 & 0.20 & 0.23 & 0.25 & 0.26 & 0.26 & 0.26 & 0.26 & 0.26 & 0.26 \\
\hline & 3.0 & 0.08 & 0.09 & 0.10 & 0.09 & 0.09 & 0.09 & 0.09 & 0.09 & 0.10 \\
\hline & 4.0 & 0.06 & 0.06 & 0.06 & 0.06 & 0.06 & 0.06 & 0.06 & 0.06 & 0.06 \\
\hline & 5.0 & 0.0431 & 0.0432 & 0.0441 & 0.0418 & 0.0415 & 0.0414 & 0.0407 & 0.0411 & 0.0440 \\
\hline & 7.0 & 0.0244 & 0.0227 & 0.0226 & 0.0205 & 0.0204 & 0.0203 & 0.0197 & 0.0201 & 0.0222 \\
\hline & 10.0 & 0.0092 & 0.0075 & 0.0071 & 0.0059 & 0.0059 & 0.0058 & 0.0056 & 0.0058 & 0.0067 \\
\hline & 12.0 & 0.0013 & 0.0007 & 0.0006 & 0.0004 & 0.0004 & 0.0004 & 0.0004 & 0.0004 & 0.0006 \\
\hline & 15.0 & 0.0004 & 0.0002 & 0.0002 & 0.0001 & 0.0001 & 0.0001 & 0.0001 & 0.0001 & 0.0002 \\
\hline \multirow[t]{12}{*}{${ }^{169} \mathrm{Yb}$} & 0.2 & 20.85 & 23.15 & 22.34 & 23.20 & 23.05 & 23.14 & 23.29 & 23.07 & 22.93 \\
\hline & 0.3 & 10.41 & 11.61 & 11.19 & 11.63 & 11.56 & 11.61 & 11.68 & 11.57 & 11.49 \\
\hline & 0.5 & 4.09 & 4.58 & 4.41 & 4.58 & 4.56 & 4.58 & 4.61 & 4.57 & 4.53 \\
\hline & 1.0 & 1.10 & 1.25 & 1.19 & 1.24 & 1.24 & 1.24 & 1.25 & 1.24 & 1.23 \\
\hline & 2.0 & 0.30 & 0.34 & 0.32 & 0.34 & 0.34 & 0.34 & 0.34 & 0.34 & 0.33 \\
\hline & 3.0 & 0.14 & 0.16 & 0.15 & 0.16 & 0.16 & 0.16 & 0.16 & 0.16 & 0.16 \\
\hline & 4.0 & 0.08 & 0.10 & 0.09 & 0.09 & 0.09 & 0.09 & 0.09 & 0.09 & 0.09 \\
\hline & 5.0 & 0.0536 & 0.0625 & 0.0574 & 0.0592 & 0.0589 & 0.0591 & 0.0592 & 0.0589 & 0.0587 \\
\hline & 7.0 & 0.0279 & 0.0321 & 0.0292 & 0.0297 & 0.0296 & 0.0297 & 0.0296 & 0.0296 & 0.0297 \\
\hline & 10.0 & 0.0133 & 0.0149 & 0.0133 & 0.0133 & 0.0132 & 0.0132 & 0.0131 & 0.0132 & 0.0134 \\
\hline & 12.0 & 0.0087 & 0.0096 & 0.0086 & 0.0085 & 0.0083 & 0.0083 & 0.0082 & 0.0082 & 0.0086 \\
\hline & 15.0 & 0.0050 & 0.0054 & 0.0048 & 0.0046 & 0.0045 & 0.0045 & 0.0044 & 0.0045 & 0.0047 \\
\hline
\end{tabular}


Table 7. Cont.

\begin{tabular}{|c|c|c|c|c|c|c|c|c|c|c|}
\hline \multicolumn{2}{|c|}{$r(\mathrm{~cm})$} & \multirow{2}{*}{$\begin{array}{l}\text { Adipose } \\
\text { tissue }\end{array}$} & \multirow{2}{*}{$\begin{array}{l}\text { Breast } \\
\text { tissue }\end{array}$} & \multirow{2}{*}{$\begin{array}{c}\text { Soft } \\
\text { tissue } \\
\text { (4-compo- } \\
\text { nent) }\end{array}$} & \multirow{2}{*}{$\begin{array}{l}\begin{array}{c}\text { Brain } \\
\text { (grey/ } \\
\text { white } \\
\text { matter) }\end{array} \\
\text { Dose }\end{array}$} & \multirow{2}{*}{$\begin{array}{l}\text { Muscle } \\
\text { (skeletal) }\end{array}$} & \multirow{2}{*}{$\begin{array}{l}\text { Lung } \\
\text { tissue } \\
\text { J-1) }\end{array}$} & \multirow{2}{*}{$\begin{array}{c}\text { Blood } \\
\text { (whole) }\end{array}$} & \multirow{2}{*}{$\begin{array}{c}\text { Soft } \\
\text { tissue } \\
\text { (9-compo- } \\
\text { nent) }\end{array}$} & \multirow[t]{2}{*}{ Water } \\
\hline & & & & & & & & & & \\
\hline \multirow[t]{12}{*}{$192 \mathrm{Ir}$} & 0.2 & 28.38 & 28.20 & 28.13 & 28.30 & 28.16 & 28.20 & 28.16 & 28.16 & 28.42 \\
\hline & 0.3 & 12.58 & 12.50 & 12.47 & 12.54 & 12.48 & 12.50 & 12.48 & 12.48 & 12.60 \\
\hline & 0.5 & 4.53 & 4.50 & 4.49 & 4.52 & 4.50 & 4.50 & 4.50 & 4.50 & 4.54 \\
\hline & 1.0 & 1.14 & 1.13 & 1.13 & 1.13 & 1.13 & 1.13 & 1.13 & 1.13 & 1.14 \\
\hline & 2.0 & 0.29 & 0.29 & 0.28 & 0.29 & 0.28 & 0.29 & 0.28 & 0.28 & 0.29 \\
\hline & 3.0 & 0.13 & 0.13 & 0.13 & 0.13 & 0.13 & 0.13 & 0.13 & 0.13 & 0.13 \\
\hline & 4.0 & 0.07 & 0.07 & 0.07 & 0.07 & 0.07 & 0.07 & 0.07 & 0.07 & 0.07 \\
\hline & 5.0 & 0.0459 & 0.0461 & 0.0457 & 0.0460 & 0.0458 & 0.0458 & 0.0458 & 0.0458 & 0.0461 \\
\hline & 7.0 & 0.0231 & 0.0233 & 0.0230 & 0.0231 & 0.0230 & 0.0230 & 0.0230 & 0.0230 & 0.0232 \\
\hline & 10.0 & 0.0136 & 0.0138 & 0.0135 & 0.0136 & 0.0135 & 0.0135 & 0.0135 & 0.0135 & 0.0137 \\
\hline & 12.0 & 0.0108 & 0.0110 & 0.0108 & 0.0108 & 0.0107 & 0.0107 & 0.0107 & 0.0107 & 0.0109 \\
\hline & 15.0 & 0.0072 & 0.0074 & 0.0072 & 0.0072 & 0.0071 & 0.0071 & 0.0071 & 0.0071 & 0.0073 \\
\hline
\end{tabular}

a non-negligible error in dose delivery especially in points far from the source model. By introducing organ specific density and composition into the TPS and dose calculation, it would be possible to avoid this error. Since the report No. 24 of ICRU has recommended that the accuracy required for tumor dose delivery in radiotherapy is $\pm 5 \%$ [36] the above effects are considerable, and a TPSs, which incorporating the differences in various soft tissues are capable of calculating dose distribution more accurately.

As it can be seen from the data in Table 6 and Table 7, while ${ }^{103} \mathrm{Pd},{ }^{125} \mathrm{I}$, and ${ }^{169} \mathrm{Yb}$ source models in adipose tissue, breast tissue, 4-component soft tissue, and water illustrate greatest difference in dose relative to the dose to the 9-component soft tissue, respectively, the other soft tissues show lower dose differences. Although the dose differences for other soft tissues are lower, this fact is not negligible. A detailed discussion on the effect of material composition on dose distribution (by considering the weight fraction of each element in the material) may be difficult, but the composition effect can be incorporated by considering the effective atomic number $\left(Z_{\text {eff }}\right)$ of the soft tissues and water. A comparison of $Z_{\text {eff }}$ and mass energy absorption coefficient of water and soft tissues as presented in Table 3. This indicates that, with some exceptions, the $Z_{\text {eff }}$ and mass energy absorption coefficient for adipose, breast and 4-component soft tissue are lower than other soft tissues. This can explain the higher dose differences of these tissues compared to the other tissues. However, it should be noted that the data in Table 3 and Table 4 are related to only a number of selected photon energies, but all the photon energies emitted by the source models effect the dose differences for various tissues (Tables 6 and 7). As it can be seen in Table 2, $Z_{\text {eff }}$ and mass energy absorption coefficient of soft tissues in higher energies have similar values, for example in $300 \mathrm{keV}$
Table 8. Average photon energy for ${ }^{103} \mathrm{Pd},{ }^{125} \mathrm{I},{ }^{169} \mathrm{Yb}$, and ${ }^{192}$ Ir sources at $0.2,1,5,10$, and $15 \mathrm{~cm}$ distances in a 9-component soft tissue phantom

Source Radial distance from the source $(\mathrm{cm})$

\begin{tabular}{lccccc} 
& 0.2 & 1 & 5 & 10 & 15 \\
\hline${ }^{103} \mathrm{Pd}$ & 38.74 & 37.30 & 38.55 & 75.04 & 128.70 \\
\hline $125 \mathrm{I}$ & 31.16 & 30.79 & 30.48 & 30.77 & 31.26 \\
\hline${ }^{169} \mathrm{Yb}$ & 114.31 & 108.90 & 95.80 & 90.77 & 88.70 \\
\hline $192 \mathrm{r}$ & 356.50 & 330.65 & 233.09 & 180.23 & 154.62
\end{tabular}

the maximum difference in $Z_{\text {eff }}$ and mass energy absorption coefficient of soft tissues are only 0.3869 and 0.00033 , respectively. Therefore, values around 1 for relative dose with respect to 9-component soft tissue can be predictable in the case of ${ }^{192} \mathrm{Ir}$ source model.

The results showed the largest relative dose difference occurred for low energy source models $\left({ }^{103} \mathrm{Pd}\right.$ and $\left.{ }^{125} \mathrm{I}\right)$, Table 6 . This effect can be justified with considering this fact that photoelectric effect has a role in absorption of radiation in soft tissue. The probability of this effect decreases with increase of photon energy. And since the photoelectric effect is inversely proportional to the third power of photon energy $\left(1 / E^{3}\right)$, the absorbed dose difference with 9-component soft dose is higher for lower photon source models, such as ${ }^{103} \mathrm{Pd}$ and ${ }^{125} \mathrm{I}$, and decreases with energy to its lowest values for ${ }^{192}$ Ir source. In a study by Melhus and Rivard [37], the effect of phantom size, phantom material, mode of radiation transport, volume averaging, and Monte Carlo tally type were studied. ${ }^{125} \mathrm{I}$ and ${ }^{103} \mathrm{Pd}$ sources showed the maximum sensitivity to phantom material between tissue substitutes and water, 
A

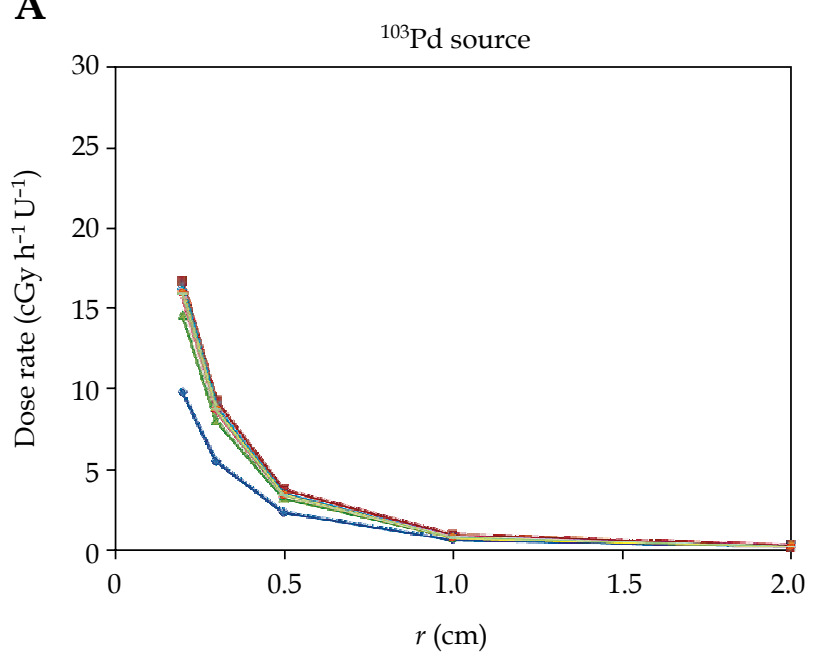

C

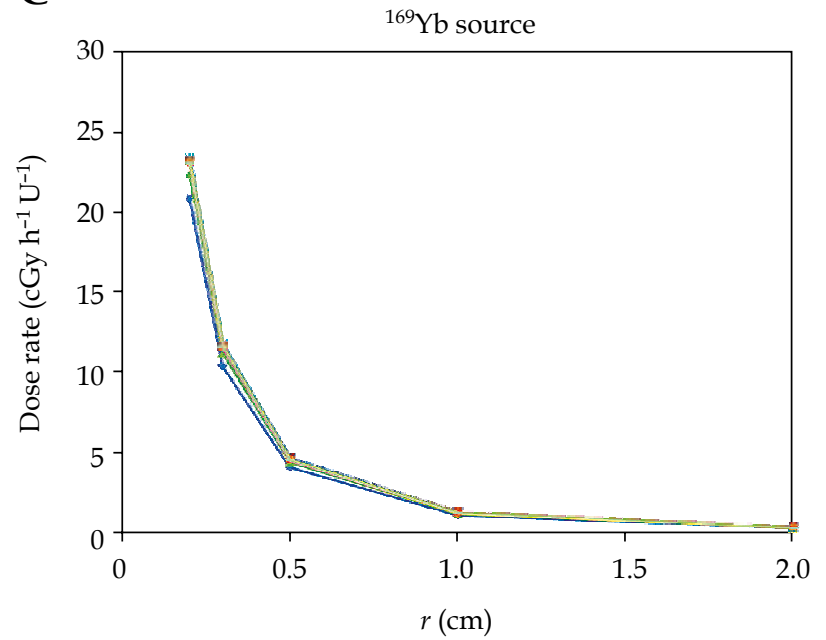

B

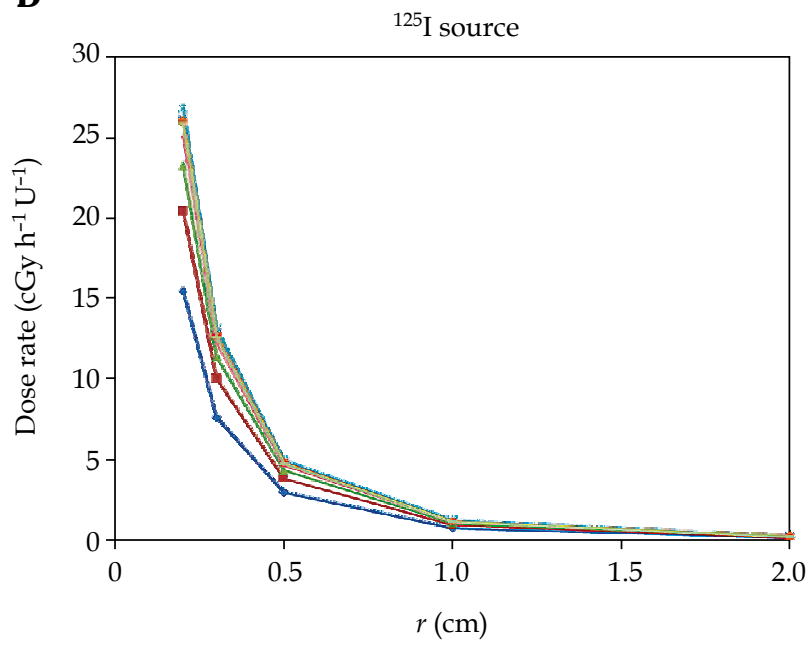

D

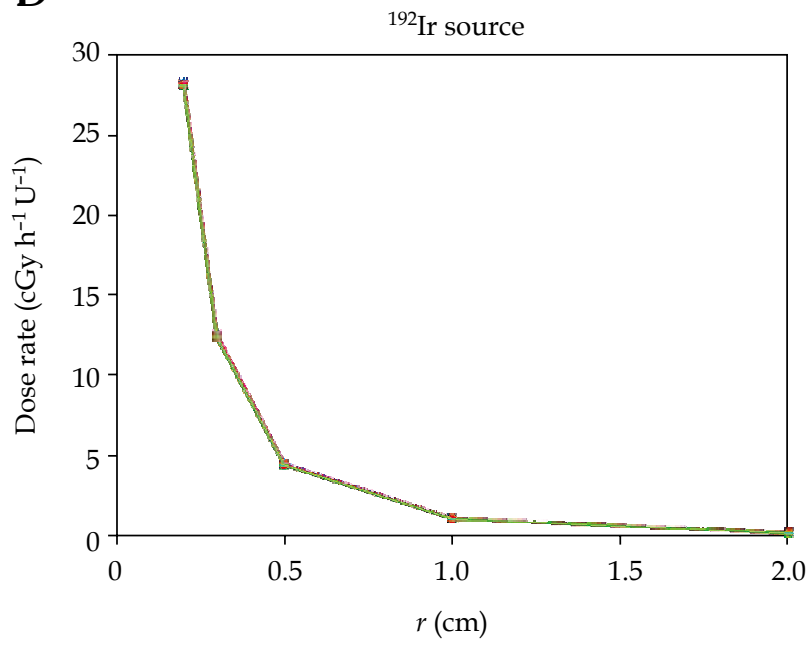

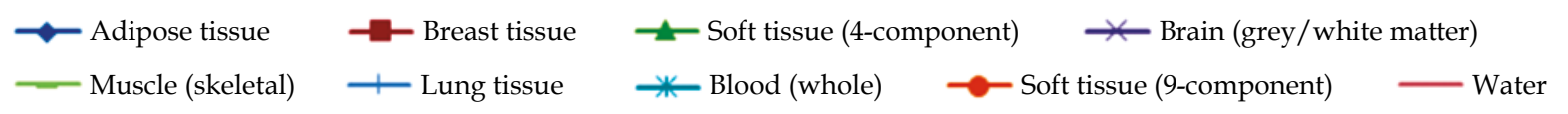

Fig. 2. Dose rate $\left(\mathrm{cGy} \mathrm{h}^{-1} \mathrm{U}^{-1}\right)$ in various soft tissues for: (A) ${ }^{103} \mathrm{Pd},(\mathrm{B}){ }^{125} \mathrm{I},(\mathrm{C}){ }^{169} \mathrm{Yb}$, and (D) ${ }^{192} \mathrm{Ir}$ brachytherapy sources

by a factor of 1.4 and 2.0 at $9 \mathrm{~cm}$ distance from the source, respectively. Furthermore, it has been shown that there are $\pm 5 \%$ differences in dose distributions for ${ }^{137} \mathrm{Cs},{ }^{192} \mathrm{Ir}$, and ${ }^{169} \mathrm{Yb}$ high-energy photon emitting sources between water and tissue-equivalent materials at $20 \mathrm{~cm}$ distance from the source. Due to the differences in methodologies between the present study and the study by Melhus and Rivard, it may not be appropriate to have a point by point comparison between the results of these two studies. A difference between these two studies is that in the present study various soft tissues and water were evaluated. In the study by Melhus and Rivard, various tissue-equivalent materials were compared with water. However, it can be concluded that both studies have shown that: the phantom material can affect the dose distribution in brachytherapy and it depends on the radial distance from the source and source's photon energy.
The results obtained in the present study are geometry-specific and are valid only for the simulated source models. For example the photon spectrum of the model $6711^{125}$ I source (due to silver ( $\mathrm{Ag}$ ) characteristic $\mathrm{X}$ rays) is somewhat different from the model $6702{ }^{125}$ I source and this phenomenon will affect the dose distribution results in various soft tissues. Although some of brachytherapy sources such as ${ }^{192}$ Ir and ${ }^{60} \mathrm{Co}$ can be used interchangeably in high dose rate (HDR) brachytherapy practice [38,39], dose distribution in various soft tissues may differ for other lower energy brachytherapy source models, and in clinical practice it cannot be sufficient to simply apply the results of this study to sources with different energies.

With interpretation of the relative dose data in Table 6, and ignoring a few exceptions, it is evident that the relative dose increases with distance from the source model for the various soft tissues and water. Thus, it can be con- 
A

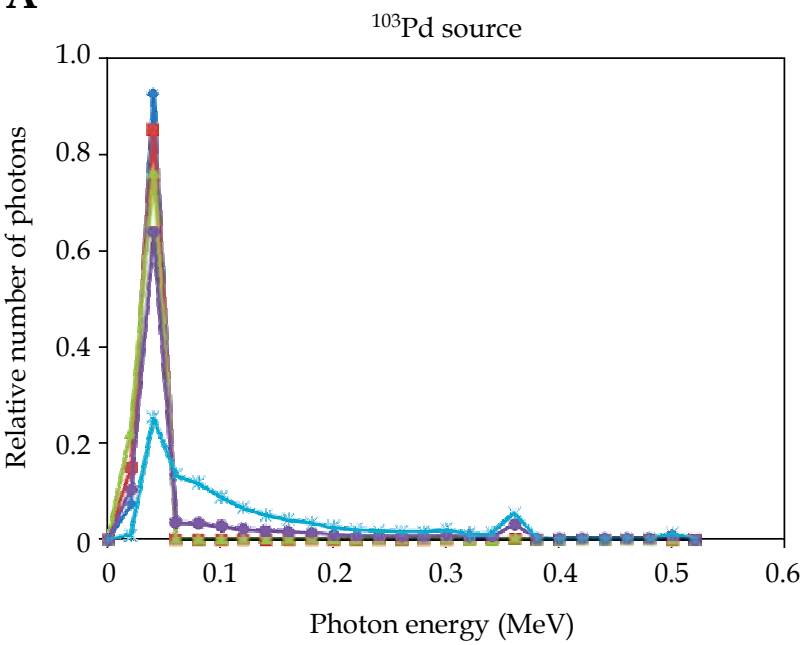

C

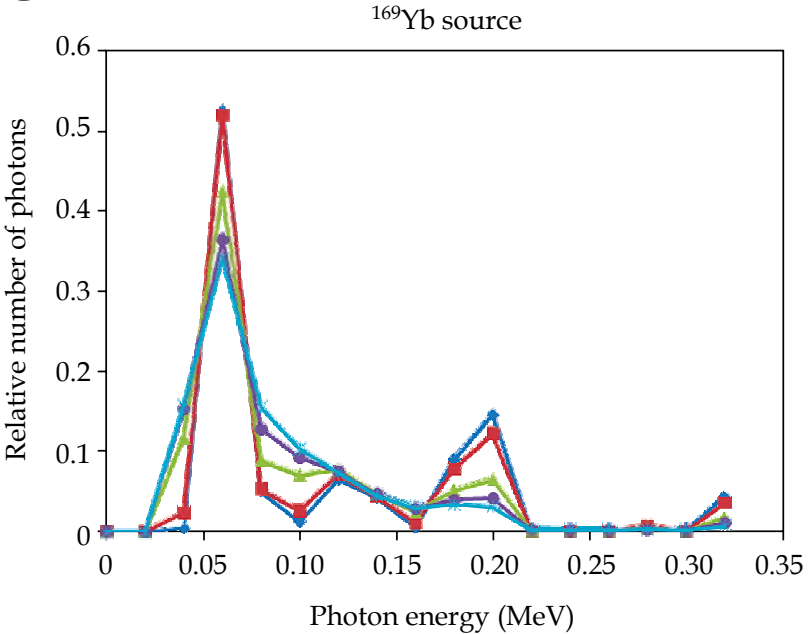

B

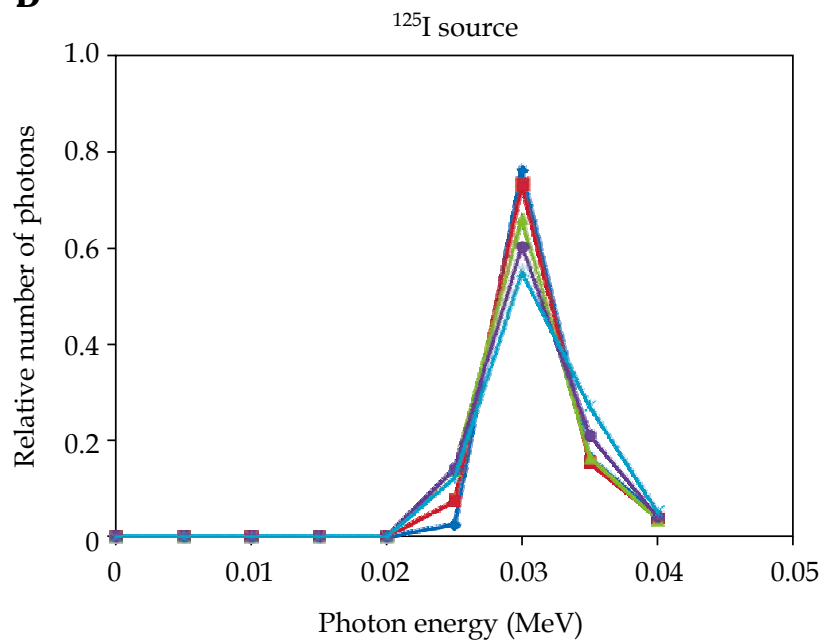

D

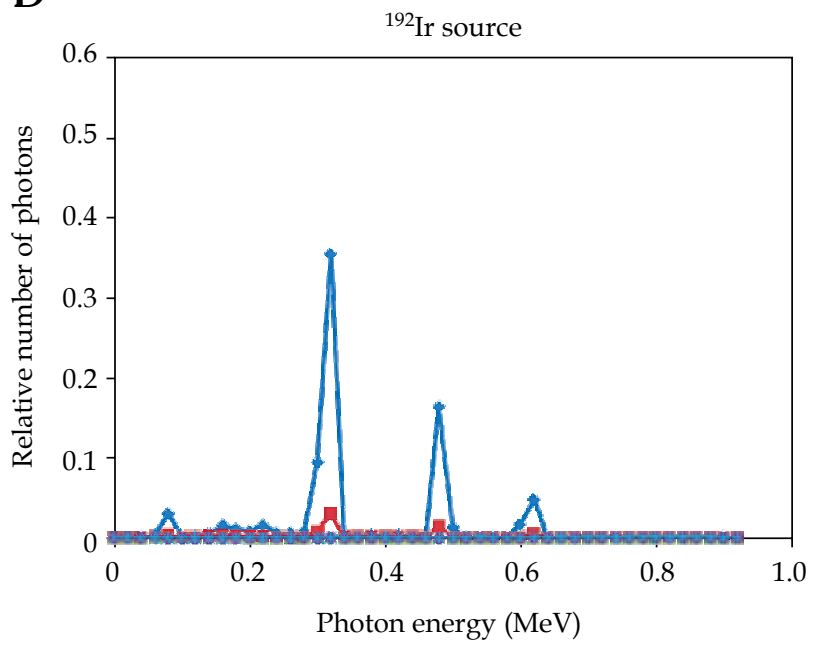

$5.0 \mathrm{~cm} \quad-10 \mathrm{~cm}$

Fig. 3. Photon spectrum at $0.2,1,5,10$, and $15 \mathrm{~cm}$ distances from the source in 9-component soft tissue. A: ${ }^{103} \mathrm{Pd}$ source; B: ${ }^{125} \mathrm{I}$ source, C: ${ }^{169} \mathrm{Yb}$ source, and D: ${ }^{192} \mathrm{Ir}$ source

cluded that the effect of tissue composition on dose, or in other words the dose difference of soft tissues from the dose in 9-component soft tissue is more dominant at distal distances from the source. However, when comparing the absolute dose values at proximal and distal distances from the source models presented in Table 7, one sees the absolute dose difference is small, despite the high relative difference. Thus, the difference in the compositions of various soft tissues on dose has its impact mainly in the points close to the source. The effect of variation of the relative dose with distance from the source model can be related to the energy of photons and photoelectric interaction. This effect is greater for ${ }^{103} \mathrm{Pd}$ (low energy) source model and is less in the case of ${ }^{192} \operatorname{Ir}$ (high energy) source model. Furthermore, when the photons are traversing through the material (Table 8), various source models have different trends in their spectral changes with distance. While for ${ }^{103} \mathrm{Pd}$ source model the average photon energy is increased, for ${ }^{125} \mathrm{I}$ it is unchanged, for the ${ }^{169} \mathrm{Yb}$ and ${ }^{192}$ Ir source models it decreases. The reason for this effect may be absorption of a number of low energy photons in phantom near the source, for the ${ }^{103} \mathrm{Pd}$ source. For ${ }^{125}$ I source model, there is a balance between the absorption of low energy photons and decreased energy of higher energy photons. For ${ }^{169} \mathrm{Yb}$ and ${ }^{192} \mathrm{Ir}$ source models, interaction of higher energy photons crossing the phantom produces a number of low energy photons, which lower the average photon energy in the spectrum.

Figure 3 shows that for all source models there are some peaks around more probable energies emitting from each radionuclide. It is observed (Figure 3 ) that in the case of ${ }^{103} \mathrm{Pd}$, most of points at far distances on the curve are above the closer ones. However, for ${ }^{169} \mathrm{Yb}$ and ${ }^{192}$ Ir source models an inverse trend is observed and for the ${ }^{125}$ I source model there is a balance between the trends for far and near distances from the source. These trends 
can justify the change of average energy of sources with distance as indicated in Table 8.

As it was plotted in Figure 3, the photon spectrum changes with distance from the source at radial direction. It can be observed that the number of photons in different ranges of energies decreases with distance. A similar pattern is observed for the four sources. This figure can provide useful information on the behavior of photon spectrum with traverse of the photons inside the phantom for various brachytherapy source models. While the photon spectrum was only illustrated in 9-component soft tissue, the same patterns can be expected for other phantom materials. The interpretation of this figure can also be useful for justification of the dose enhancement effect of nanoparticles present in tumor, for tumors at various distances from the source [40].

In the present study, water as a tissue-equivalent media and a number of soft tissues were evaluated based on their difference in dose with respect to 9-component soft tissue. These media were evaluated as samples to illustrate their effect on dose distribution. However, there are other soft tissues with different compositions and radiation sensitivity. Performing similar evaluation on these organs as well as other tissue-equivalent materials is a subject for future studies. Furthermore, herein a homogeneous and relatively large size of phantom was filled with a soft tissue for dose calculations. In a real situation, a cross section of the body contains various soft tissues and also a bone, while in TPSs the same composition is taken for all these tissues. Based on the results of the present study, it is predicted that the variation in the composition of these tissues will change their doses relative to a situation for which the treatment planning calculates the dose distribution (a homogeneous case of soft tissue or water). A study on a real inhomogeneous contour of body, including various soft tissues by Monte Carlo or 3D dose measurement method (such as gel dosimetry) and evaluation of the corresponding error compared to a homogeneous soft tissue and the error of TPS calculations would be interesting as further works in this field. In the present work, the effect of soft tissue composition was only studied only for photon energies emitted by brachytherapy sources. This effect is important in low energy photon ranges, because of dominance of photoelectric absorption in low energy range and its high dependence on atomic number of the media.

\section{Conclusions}

In this study, the effect of tissue composition on dose distribution for adipose tissue, breast tissue, 4-component soft tissue, brain (grey/white matter), muscle (skeletal), lung tissue, blood (whole), 9-component soft tissue, and water was evaluated for ${ }^{103} \mathrm{Pd},{ }^{125} \mathrm{I},{ }^{169} \mathrm{Yb}$, and ${ }^{192} \mathrm{Ir}$ sources. TPSs, which consider only a homogeneous treatment volume create errors in dose calculations. Based on the results of this study, the error depends on the type of soft tissue, brachytherapy source, as well as the distance from the source. Furthermore, water which is used widely as a tissue equivalent material in radiotherapy dosimetry protocols and TPSs has a dose distribution different from other soft tissues when used with photon emitting brachytherapy sources. The differences should be taken into account in dosimetry protocols and TPSs.

\section{Acknowledgements}

This work was based on the results of a MSc thesis, which was funded by Kermanshah University of Medical Sciences (KUMS).

\section{Disclosure}

Authors report no conflict of interest.

\section{References}

1. http://www.cancerresearchuk.org/cancer-info/cancerstats/ world; accessed: January 26, 2014.

2. Misra R, Acharya S, Sahoo SK. Cancer nanotechnology: application of nanotechnology in cancer therapy. Drug Discov Today 2010; 15: 842-850.

3. Verhaegen F, Seuntjens J. Monte Carlo modelling of external radiotherapy photon beams. Phys Med Biol 2003; 48: 107-164.

4. Palmer A, Bradley D, Nisbet A. Physics-aspects of dose accuracy in high dose rate (HDR) brachytherapy: source dosimetry, treatment planning, equipment performance and in vivo verification techniques. J Contemp Brachytherapy 2012; 4: 81-91.

5. Yohannes I, Kolditz D, Langner O et al. A formulation of tissue- and water-equivalent materials using the stoichiometric analysis method for CT-number calibration in radiotherapy treatment planning. Phys Med Biol 2012; 57: 1173-1190.

6. Juste B, Miró R, Campayo JM et al. Radiotherapy treatment planning based on Monte Carlo techniques. Nucl Instrum Methods Phys Res 2010; 619: 252-257.

7. Thomadsen BR, Williamson JF, Rivard MJ et al. Anniversary Paper: Past and current issues, and trends in brachytherapy physics. Med Phys 2008; 35: 4708-4723.

8. Rivard MJ, Venselaar JL, Beaulieu L. The evolution of brachytherapy treatment planning. Med Phys 2009; 36: 2136-2153.

9. Beaulieu L, Tedgren AC, Carrier JF et al. Report of the Task Group 186 on model-based dose calculation methods in brachytherapy beyond the TG- 43 formalism: Current status and recommendations for clinical implementation. Med Phys 2012; 39: 6208-6236.

10. Yazdani M, Mowlavi AA. Determining TG-43 brachytherapy dosimetry parameters and dose distribution for a ${ }^{131} \mathrm{Cs}$ source model CS-1. Iran J Radiat Res 2007; 5: 85-90.

11. Mowlavi AA, Yazdani M. Dosimetry parameters determination of ${ }^{169} \mathrm{Yb}$ brachytherapy source model X1267. Appl Phys Res 2010; 2: 118-124.

12. Luxton G. Comparison of radiation dosimetry in water and in solid phantom materials for I-125 and Pd-103 brachytherapy sources: EGS4 Monte Carlo study. Med Phys 1994; 21: 631-641.

13. Sahoo S, Palani Selvam T, Vishwakarma RS et al. Monte Carlo modeling of ${ }^{60} \mathrm{Co}$ HDR brachytherapy source in water and in different solid water phantom materials. J Med Phys 2010; 35: $15-22$.

14. Carlsson Tedgren A, Carlsson GA. Influence of phantom material and dimensions on experimental ${ }^{192} \mathrm{Ir}$ source. Med Phys 2009; 36: 2228-2235.

15. Chandola RM, Tiwari S, Kowar MK et al. Effect of inhomogeneities and source position on dose distribution of Nucletron high dose rate Ir-192 brachytherapy source by Monte Carlo simulation. J Cancer Res Ther 2010; 6: 54-57.

16. Cazeca MJ, Medich DC, Munro JJ 3rd. Effects of breast-air and breast-lung interfaces on the dose rate at the planning 
target volume of a MammoSite catheter for Yb-169 and Ir-192 HDR sources. Med Phys 2010; 37: 4038-4045.

17. Gialousis G, Dimitriadis A, Yakoumakis E. Monte Carlo estimation of dose difference in lung from ${ }^{192}$ Ir brachytherapy due to tissue inhomogeneity. Radiat Prot Dosimetry 2011; 147: 287-290.

18. Hsu SM, Wu CH, Lee JH et al. A study on the dose distributions in various materials from an Ir-192 HDR brachytherapy source. PLoS One 2012; 7: e44528.

19. White SA, Landry G, van Gils F et al. Influence of trace elements in human tissue in low-energy photon brachytherapy dosimetry. Phys Med Biol 2012; 57: 3585-3596.

20. ICRU. ICRU Report No. 44, Tissue substitutes in radiation dosimetry and measurement. ICRU, Bethesda 1989.

21. Waters LS. MCNPX User's Manual. 2000; Version 2.4.0. Report LA-CP-02-408 (Los Alamos, NM: Los Alamos National Laboratory).

22. http://www.physics.carleton.ca/clrp/seed_database/Pd103/ Prospera_Med3633_ideal; accessed: January 26, 2014, Carleton University.

23. http://www.physics.carleton.ca/clrp/seed_database/I125/ OncoSeed_6702; accessed: January 26, 2014, Carleton University.

24. http://www.physics.carleton.ca/clrp/seed_database/Yb169_ HDR/HDR_4140; accessed: January 26, 2014, Carleton University.

25. http://www.physics.carleton.ca/clrp/seed_database/ Ir192_HDR/GammaMed_12i; accessed: January 26, 2014, Carleton University.

26. Rivard MJ, Coursey BM, DeWerd LA et al. Update of AAPM Task Group No. 43 Report: A revised AAPM protocol for brachytherapy dose calculations. Med Phys 2004; 31: 633-674.

27. Cazeca MJ, Medich DC, Munro JJ III. Monte Carlo characterization of a new $\mathrm{Yb}-169$ high dose rate source for brachytherapy application. Med Phys 2010; 37: 1129-1136.

28. Medich DC, Munro JJ III. Monte Carlo characterization of the M-19 high dose rate Iridium-192 brachytherapy source. Med Phys 2007; 34: 1999-2006.

29. DeWerd LA, Ibbott GS, Meigooni AS et al. A dosimetric uncertainty analysis for photon-emitting brachytherapy sources: Report of AAPM Task Group No. 138 and GEC-ESTRO. Med Phys 2011, 38: 782-801.

30. http://physics.nist.gov/PhysRefData/XrayMassCoef/tab4. html; accessed: January 26, 2014, National Institute of Standards and Technology.

31. Taylor ML, Smith RL, Dossing F et al. Robust calculation of effective atomic numbers: The Auto- $Z_{\text {eff }}$ software. Med Phys 2012; 39: 1769-1778.

32. Rivard MJ. A discretized approach to determining TG-43 brachytherapy dosimetry parameters: case study using Monte Carlo calculations for the MED $3633{ }^{103} \mathrm{Pd}$ source. Appl Radiat Isot 2001; 55: 775-782.

33. Taylor RE, Rogers DW. An EGSnrc Monte Carlo-calculated database of TG-43 parameters. Med Phys 2008; 35: 4228-4241.

34. Pérez-Calatayud J, Ballester F, Serrano-Andrés MA et al. Dosimetry characteristics of the Plus and 12i Gammamed PDR ${ }^{192}$ Ir sources. Med Phys 2001; 28: 2576-2585.

35. Rivard MJ, Butler WM, DeWerd LA et al. Supplement to the 2004 update of the AAPM Task Group No. 43 Report. Med Phys 2007; 34: 2187-2205.

36. ICRU report No.24. Determination of absorbed dose in a patient irradiated by beams of $X$ or gamma rays in radiotherapy procedures. International Commission on Radiation Units and Measurements (ICRU), Washington 1976.

37. Melhus CS, Rivard MJ. Approaches to calculating AAPM TG-43 brachytherapy dosimetry parameters for ${ }^{137} \mathrm{Cs},{ }^{125} \mathrm{I}$, ${ }^{192} \mathrm{Ir},{ }^{103} \mathrm{Pd}$, and ${ }^{169} \mathrm{Yb}$ sources. Med Phys 2006; 33: 1729-1737.
38. Palmer A, Hayman O, Muscat S. Treatment planning study of the 3D dosimetric differences between Co-60 and Ir-192 sources in high dose rate (HDR) brachytherapy for cervix cancer. J Contemp Brachyther 2012; 4: 52-59.

39. Strohmaier S, Zwierzchowski G. Comparison of ${ }^{60} \mathrm{Co}$ and ${ }^{192} \mathrm{Ir}$ sources in HDR brachytherapy. J Contemp Brachytherapy 2011; 3: 199-208.

40. Bahreyni Toossi MT, Ghorbani M, Mehrpouyan M et al. A Monte Carlo study on tissue dose enhancement in brachytherapy: a comparison between gadolinium and gold nanoparticles. Australas Phys Eng Sci Med 2012; 35: 177-185. 